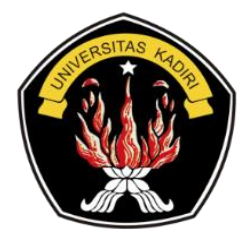

Tersedia secara online di http://ojs.unik-kediri.ac.id/index.php/jatiunik/issue/view/76

\title{
Penerapan Metode Saving Matrix Dan Algoritma Nearest Neighbor Dalam Menentukan Rute Distribusi Untuk Meminimalkan Biaya Transportasi Pada PT. XYZ
}

\author{
Viva Arfana Perdana ${ }^{* 1}$, Zenny Fatimah Hunusalela*2 ${ }^{*}$ Aliffia Teja Prasasty ${ }^{* 3}$ \\ ${ }^{1}$ Program Studi Teknik Industri, Fakultas Teknik dan Ilmu Komputer, Universitas Indraprasta PGRI, \\ Jl. Raya Tengah Kel. Gedong - Jl. Nangka No. 58C Tanjung Barat \\ Email: vapdanul@gamil.com
}

Informas $\boldsymbol{i}$ Artike
Riwayat Artikel :
Received : 5 - Agustus - 2020
Revised : 10 - Oktober - 2020
Accepted: 17 - Oktober - 2020

Kata kunci :

Distribusi

Nearest Neighbor

Saving Matrix

Topic

\begin{abstract}
PT. XYZ is a manufacturing industry company engaged in drinking water, this company still has problems in its distribution, the existence of undirected shipping or waste of transportation distribution costs for shipping in several regions because shipping in the area uses only one vehicle at each destination resulting in delivery distance getting longer. Therefore, this research was conducted to improve distribution costs using the saving matrix method and the nearest neighbor algorithm. The results of the company's distribution costs are Rp. 18,940,924 / month after using this method the distribution cost becomes Rp. 16,302,392 / month and with the saving matrix method and the nearest neighbor algorithm, it saves $16 \%$ of the cost proposed by the company.
\end{abstract}

Untuk melakukan sitasi pada penelitian ini dengan format : Muhammad, Bakhtiar, and M. Rahmi, "Penentuan Rute Transportasi Distribusi Sirup Untuk Meminimalkan Biaya," Ind. Eng. J., vol. 6, no. 1, pp. 1015,2017

\begin{abstract}
A b s t rak
PT. XYZ adalah perusahaan industri manufaktur yang bergerak dibidang air minum, perusahaan ini masih terdapat permasalahan dalam distribusinya, adanya pengiriman yang tidak terarah atau pemborosan biaya distribusi transportasi untuk pengiriman beberapa daerah dikarnakan pengiriman di daerah tersebut hanya menggunakan satu kendaraan pada masing masing tujuan yang mengakibatkan jarak pengiriman semakin panjang. Sebab itu penelitian ini dilakukan guna memperbaiki biaya distribusinya menggunakan metode saving matrix dan algoritma nearest neighbor. Hasil biaya distribusi perusahaan yaitu Rp. 18.940.924 / bulan setelah menggunakan metode tersebut biaya distribusinya menjadi Rp. 16.302.392 / bulan serta
\end{abstract}


dengan metode saving matrix dan algoritma nearest neighbor jadi lebih menghemat $16 \%$ dari biaya yang diusulkan dari perusahaan.

\section{Pendahuluan}

Pada era globalisasi saat ini di dunia industri sangat berkembang pesat semua perusahaan berlomba-lomba untuk menemukan sebuah solusi yang tepat agar dapat bertahan dan memenangkan persaingan di dalam dunia bisnis. Sukses tidak suatu perusahaan ditentukan oleh manajamen yang baik, adanya persaingan semakin ketat antar perusahaan mendorong setiap perusahaan untuk tercapainya tujuan tersebut apabila perusahan dapat mempertahankan dan meningkatkan penjualannya. Serta dapat menekan biaya yang dikeluarkan salah satu biaya operasional yang penting bagi perusahaan yaitu biaya trasportasi yang merupakan faktor yang cukup berpengaruh bagi keberhasilan perusahaan dalam menjual produknya dalam masalah distribusi. Distribusi dan transportasi yang baik merupakan hal penting agar produk dapat dikirim sampai ke konsumen secara tepat waktu, tepat pada tempat yang telah dilakukan dan produk dalam kondisi baik [1], [2], [3], [4]. Keputusan penentuan jadwal serta rute pengiriman menjadi sesuatu yang penting dalam rangka meminimumkan biaya pengiriman, meminimumkan waktu atau jarak tempuh [5], [6], [7], [8].

PT. XYZ merupakan perusahaan industri manufaktur yang bergerak dibidang air minum, perusahaan memporduksi air mineral yang berbentuk gelas atau cup maupun botol air mineral. Perusahaan ini memproduksi setiap harinya yaitu 6000 box/dus. Tetapi perusahan ini dalam mengoperasikan pengirimannya belum memiliki pengukuran tersendiri dalam menentukan rute pengiriman, sehingga terjadi pengeluaran biaya yang besar. Berikut ini pada tabel I adalah data permintaan customer dengan rute kapasitas yang dimiliki oleh perusahaan.

Tabel I. Data Permasalahan di Perusahaan

\begin{tabular}{|c|c|c|c|c|c|c|c|c|}
\hline Dari & Tujuan & $\begin{array}{l}\text { Pengiriman } \\
\text { (Box) }\end{array}$ & $\begin{array}{l}\text { Jarak } \\
(\mathrm{Km})\end{array}$ & $\begin{array}{c}\text { Kapasitas } \\
\text { (Box) }\end{array}$ & $\begin{array}{c}\text { Jenis } \\
\text { Truck }\end{array}$ & $\begin{array}{c}\text { Biaya } \\
\text { BBM (Rp) }\end{array}$ & $\begin{array}{c}\text { Biaya } \\
\text { Retribusi } \\
\text { (Rp) }\end{array}$ & $\begin{array}{l}\text { Total Biaya } \\
\text { (Rp) }\end{array}$ \\
\hline \multirow{14}{*}{ Kranggan } & Bekasi & 300 & 52 & 600 & CLD-2 & 81.466 & 50.000 & 131.466 \\
\hline & Karawang & 150 & 132 & 600 & CLD-4 & 206.800 & 50.000 & 256.800 \\
\hline & Cibinong & 120 & \multirow{2}{*}{105} & 600 & CLD-3 & \multirow{2}{*}{164.500} & 50.000 & \multirow{2}{*}{264.500} \\
\hline & Jonggol & 210 & & 600 & CLD-3 & & 50.000 & \\
\hline & Cengkareng & 200 & \multirow{2}{*}{05} & 600 & CLD-1 & \multirow{2}{*}{164.500} & 50.000 & \multirow{2}{*}{264.500} \\
\hline & Tanjung priok & 200 & & 600 & CLD-1 & & 50.000 & \\
\hline & Bogor & 150 & \multirow{3}{*}{96} & 600 & CLD-6 & \multirow{3}{*}{150.400} & 50.000 & \multirow{3}{*}{300.400} \\
\hline & Depok & 180 & & 600 & CLD-6 & & 50.000 & \\
\hline & Ciracas & 100 & & 600 & CLD-6 & & 50.000 & \\
\hline & Jakarta & 200 & \multirow{2}{*}{121} & 600 & CLD-7 & \multirow{2}{*}{189.566} & 50.000 & \multirow{2}{*}{289.566} \\
\hline & Tangerang & 150 & & 600 & CLD-7 & & 50.000 & \\
\hline & Subang & 100 & \multirow{2}{*}{50} & 600 & CLD-8 & \multirow{2}{*}{391.666} & 20.000 & \multirow{2}{*}{461.666} \\
\hline & Cikampek & 340 & & 600 & CLD-8 & & 50.000 & \\
\hline & Solo & 200 & 1070 & 600 & CLD-5 & 1.676 .333 & 400.000 & 2.076 .333 \\
\hline & 2600 & 1931 & & & & & 4.045 .231 \\
\hline
\end{tabular}

Sumber: PT. XYZ 
Pada tabel I dapat dilihat adanya pengiriman yang tidak terarah atau pemborosan biaya distribusi transportasi untuk pengiriman menuju Bekasi, Karawang, Solo dikarnakan pengiriman di daerah tersebut hanya menggunakan satu kendaraan pada masing masing tujuan yang mengakibatkan jarak pengiriman semakin panjang, hal ini bisa dapat menyebabkan kerugian pada perusahaan karna biaya yang dikeluarkan akan bertambah sedangkan jika dalam satu daerah bisa saja mengirimkan pada beberapa customer dengan jalur tempuh dan waktu yang sama, biaya pengiriman otomatis akan lebih kecil dari biaya pertama.

\section{Tinjauan Pustaka}

Menurut Drs, H.A Abbas Salim (2008:P6) Transportasi sebagai dasar untuk pembangunan ekonomi dan perkembangan masyarakat serta pertummbuhan industrialisasi. Metode Transportasi adalah suatu metode yang digunakan untuk mengatur distribusi dari sumber-sumber yang menyediakan produk yang sama ke tempat-tempat tujuan yang optimal. Distribusi ini dilakukan sedemikian rupa sehingga permintaan dari beberapa tempat tujuan dapat dipenuhi dari beberapa tempat asal (sumber), yang masing-masing dapat memiliki permintaan atau kapasitas yang berbeda. Alokasi ini dilakukan dengan mempertimbangkan biaya pengankutan yang bervariasi karena jarak dan kondisi antar lokasi yang berbeda. Dengan menggunakan metode transportasi, dapat memnimalkan biaya total transportasi [9], [10]

Distribusi mencakup semua aspek dalam pengiriman produk kepada konsumen. Menurut [11] menyatakan bahwa saluran distribusi adalah suatu jalur yang dilalui oleh arus barang-barang dari produsen ke perantara dan akhirnya sampai kepada pemakai. Selain itu, distribusi juga dapat diartikan sebagai lembaga-lembaga penyalur yang mempunyai kegiatan untuk menyalurkan barang-barang atau jasa-jasa dari produsen ke konsumen .

Metode savings matrix juga merupakan salah satu teknik yang digunakan untuk menjadwalkan sejumlah kendaraan terbatas dari fasilitas yang memiliki kapasitas maksimum. Manfaat penelitian ini diharapkan bisa dijadikan referensi dalam pengaplikasian metode savings matrix dalam meminimalkan biaya pengiriman dan memberikan masukan bagi perusahaan untuk merancang jadwal pendistribusian yang efektif dan efisien untuk meminimasi biaya transportasi, penentuan kapasitas dan penggunaan jumalah kendaraan yang tepat

Metode Nearest Neighbor yaitu menentukan urutan kunjungan dengan mengutamakan lokasi yang jaraknya paling dekat dengan lokasi yang dikunjungi terakhir [12], [13].

Metode Nearest Neighbor bertujuan untuk menentukan rute terpendek sehingga jalur distribusi dapat dilakukan secara optimal. Optimal yang dimaksud adalah jumlah barang yang dikirim, waktu pengiriman, dan jarak yang dibutuhkan tepat [14].

\section{Metode Penelitian}

Penelitian berlangsung pada bulan September 2019 di PT. Kranggan Tirta Lestari (KTL), perusahaan ini adalah perusahaan yang berdiri berdasarkan SK.Menkum HAM No.C-357.HT03.01- tahun 2006. Perusahan ini bergerak dibidang produksi dan distribusi Air Minum Dalam Kemasan (AMDK) cup atau botol, PT. Kranggan Tirta Lestari (KTL) memulai operasiaonal tanggal 19 Februari 2019. Perusahaan ini beralamat di Jl.Lembur I, Kel. Jatirangga, Kec Jatisampurna Kota Bekasi. 


\subsection{Metode saving matrix}

Metode saving matrix adalah metode yang digunakan untuk menentukan rute terbaik dengan mempertimbangkan jarak yang dilalui, jumlah kendaraan yang akan digunakan dan jumlah produk yang dapat dimuat kendaraan dalam pengiriman produk ke konsumen agar proses distribusi optimal [15], [16].

Metode savings matrix juga merupakan salah satu teknik yang digunakan untuk menjadwalkan sejumlah kendaraan terbatas dari fasilitas yang memiliki kapasitas maksimum [17], [18], [19], [20].

Metode savings matrix terdiri dari beberapa langkah-langkah dalam metode saving matriks adalah sebagai berikut :

1. Menentukan matriks jarak.

Pada penentuan matrix jarak ini, data jarak antara perusahaan dengan lokasi dan lokasi ke lokasi lainnya sangat diperlukan. Setelah mengetahui koordinat dari masing-masing lokasi, maka jarak antar kedua lokasi tersebut dapat dihitung dengan menggunakan rumus [8] :

$$
\mathrm{J}(1,2)=\sqrt{\left(X_{a}-X_{b}\right)^{2}+\left(Y_{a}-Y_{b}\right)^{2}}
$$

Dimana : J $(1,2)=$ Jarak antara titik 1 dan 2

$\mathrm{x} 1, \mathrm{y} 1=$ Koordinat titik 1

$\mathrm{x} 2, \mathrm{y} 2=$ Koordinat titik 2

2. Menentukan matriks penghematan (savings matrix)

Setelah mengetahui jarak keseluruhan yaitu jarak antara pabrik dengan lokasi dan lokasi dengan lokasi yang lainnya, maka dalam langkah ini diasumsikan bahwa setiap lokasi akan dilewati oleh satu truk secara ekslusif [21], [22], [23].
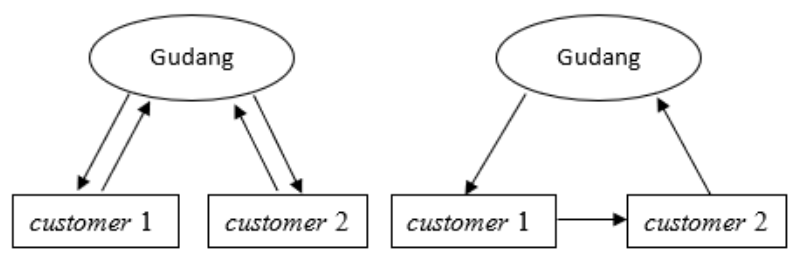

Gambar 1 Perubahan yang terjadi dengan menggabungkan customer 1 dan customer 2 kedalam satu rute.

Didalam itu matriks penghematan dapat digunakan rumus sebagai berikut :

$\mathrm{S}(\mathrm{x}, \mathrm{y})=\mathrm{J}(\mathrm{x}, \mathrm{y})+\mathrm{J}(\mathrm{x}, \mathrm{y})-\mathrm{J}(\mathrm{x}, \mathrm{y})$

$\mathrm{S}(\mathrm{x}, \mathrm{y})$ merupakan penghematan jarak yaitu dari penggabungan rute $\mathrm{x}$ dengan rute $\mathrm{y}$.

3. Pengalokasian kendaraan dan rute berdasarkan lokasi

Untuk pengalokasian kendaraan berdasarkan lokasi diperlukan pengecekan apakah pergabungan tersebut layak atau tidak berdasarkan kapasitas yang ada berdasarkan rumus berikut :

Rute $1+$ order size customer $1+$ order size customer $2+$ customer $-\mathrm{n}$.

Keterangan :

Order size customer 1 = Banyaknya produk yang diangkut untuk pelanggan ke 1 
Order size customer 2 = Banyaknya produk yang diangkut untuk pelanggan ke 2 Order size customer $\mathrm{n}=$ Banyaknya produk yang diangkut untuk pelanggan ke $\mathrm{n}$ Order size rute $1<$ kapasitas alat angkut

\subsection{Metode neurest neighbor}

Metode neurest neighbor merupakan metode yang digunakan untuk menentukan jarak rute terpendek dengan jarak yang paling terdekat antara customer satu dengan customer lain.

Metode Nearest Neighbor bertujuan untuk menentukan rute terpendek sehingga jalur distribusi dapat dilakukan secara optimal. Optimal yang dimaksud adalah jumlah barang yang dikirim, waktu pengiriman, dan jarak yang dibutuhkan tepat. Metode Nearest Neighbor merupakan metode paling sederhana untuk menyelesaikan masalah perjalan penjualan (Traveling Salesman Problem). Metode nearest neighbor terdiri dari beberapa langkah-langkah dalam metode tersebut adalah sebagai berikut :

1. Memilih salah satu titik yang mewakili suatu titik awal.

2. Selanjutnya, memilih titik tujuan yang akan dikunjungi berikutnya, dengan pertimbangan hanya memilih titik yang memiliki jarak terdekat dengan titik yang sebelumnya dikunjungi.

3. Setelah seluruh titik dikunjungi atau seluruh titik telah terhubung, maka tutup rute perjalanan dengan kembali ke titik asal.

Berikut ini merupakan rumus persamaaan yang digunakan untuk menyelesaikan metode Nearest Neighbor : $\mathrm{f}=\overparen{\mathrm{b}} \mathrm{k}+\mathrm{Ckj}+\mathrm{Cij}$

Metode Nearest Neighbor digunakan pada penelitian ini dikarnakan mempunyai karakteristik pembentukan rute distribusi sesuia dengan keadaan nyata yang terdapat pada kondisi di lapangan, serta teknik penentuan rute yang ditetapkan pada metode ini lebih mudah dipahami dan metode Nearest Neighbor ini merupakan sebagai metode dasar dalam pembentukan rute distribusi menggunakan lainnya.

\section{Hasil dan Pembahasan}

PT. XYZ merupakan perusahaan industri manufaktur yang bergerak dibidang air minum, perusahaan memporduksi air mineral yang berbentuk gelas atau cup maupun botol air mineral. Perusahaan ini memproduksi setiap harinya yaitu 6000 box/dus. Pada pengumpulan data ini harus mempunyai data pengiriman produk air mineral, rute awal, data alat angkut, dan data biaya.

\subsection{Pengiriman Produk Air mineral}

Data permintaan produk Air mineral pada periode bulan September 2019

Tabel II. Data Pengiriman Produk

\begin{tabular}{cccccc}
\hline \multirow{2}{*}{ Customer } & \multicolumn{4}{c}{ Pengiriman produk Air mineral ke } & \multirow{2}{*}{ Ket } \\
\cline { 2 - 5 } & 1 & 2 & 3 & 4 & \\
\hline Customer 1 & 300 & 300 & 300 & 300 & Box \\
\hline Customer 2 & 200 & 150 & 100 & 150 & Box \\
\hline Customer 3 & 128 & 120 & 102 & 130 & Box \\
\hline Customer 4 & 300 & 200 & 190 & 150 & Box
\end{tabular}




\begin{tabular}{cccccc}
\hline Customer 5 & 100 & 100 & 300 & 300 & Box \\
\hline Customer 6 & 200 & 200 & 200 & 200 & Box \\
\hline Customer 7 & 100 & 100 & 150 & 250 & Box \\
\hline Customer 8 & 100 & 220 & 150 & 250 & Box \\
\hline Customer 9 & 50 & 100 & 150 & 100 & Box \\
\hline Customer 10 & 100 & 200 & 300 & 200 & Box \\
\hline Customer 11 & 150 & 250 & 150 & 50 & Box \\
\hline Customer 12 & 100 & 100 & 100 & 100 & Box \\
\hline Customer 13 & 350 & 260 & 350 & 400 & Box \\
\hline Customer 14 & 200 & 200 & 200 & 200 & Box \\
\hline Sumer PT. XY
\end{tabular}

Sumber: PT. XYZ

Keterangan lokasi :

Data pada tabel II merupakan data permintaan tiap minggu dalam sebualan :
$\mathrm{C} 1=$ Bekasi
$\mathrm{C} 8=$ Depok
$\mathrm{C} 2=$ Karawang
C9 = Ciracas
C3 = Cibinong
$\mathrm{C} 10=$ Jakarta
$\mathrm{C} 4$ = Jonggol
$\mathrm{C} 11=$ Tangerang
C5 $=$ Cengkareng
C12 = Subang
C6 $=$ Tanjung priok
C13 = Cikampek
$\mathrm{C} 7=$ Bogor
$\mathrm{C} 14=$ Solo

Sehingga order size dapat diambil rata-rata dari jumlah permintaan customer selama satu bulan yaitu bulan september 2019. Rata-rata untuk order size pada tabel 4.1 sebagai berikut :

$$
\begin{aligned}
& \text { Customer }=\frac{\text { Total produk yang dikirim kepada customer } 1}{\text { Jumlah pengiriman }} \\
& =\frac{1200}{4} \quad=300 \mathrm{box}
\end{aligned}
$$

Untuk perhitungan rata-rata order size selanjutnya dapat dilihat pada lampiran rata-rata

\begin{tabular}{|c|c|c|c|}
\hline No & Kode Customer & Pengiriman & $\begin{array}{c}\text { Kapasitas } \\
\text { (Box) }\end{array}$ \\
\hline 1 & $\mathrm{C} 1$ & 300 & \multirow{14}{*}{600} \\
\hline 2 & $\mathrm{C} 2$ & 150 & \\
\hline 3 & $\mathrm{C} 3$ & 120 & \\
\hline 4 & $\mathrm{C} 4$ & 210 & \\
\hline 5 & $\mathrm{C} 5$ & 200 & \\
\hline 6 & C6 & 200 & \\
\hline 7 & $\mathrm{C} 7$ & 150 & \\
\hline 8 & C8 & 180 & \\
\hline 9 & C9 & 100 & \\
\hline 10 & $\mathrm{C} 10$ & 200 & \\
\hline 11 & C11 & 150 & \\
\hline 12 & $\mathrm{C} 12$ & 100 & \\
\hline 13 & $\mathrm{C} 13$ & 340 & \\
\hline 14 & C14 & 200 & \\
\hline
\end{tabular}
order size.

Sumber: PT. XYZ

\subsection{Rute Awal}

Data rute awal yang digunakan oleh perusahaan dalam pengiriman produk snack taro kepada customer sebagai berikut. 
Tabel IV. Rute Awal Pengiriman

\begin{tabular}{cccc}
\hline Rute & Kode Customer & Jenis Armada & Jarak (Km) \\
\hline 1 & G-C5-C6-G & CLD1 & 105 \\
\hline 2 & G-C1-G & CLD2 & 52 \\
\hline 3 & G-C3-C4-G & CLD3 & 105 \\
\hline 4 & G-C2-G & CLD4 & 132 \\
\hline 5 & G-C14-G & CLD5 & 1070 \\
\hline 6 & G-C7-C8-C9-G & CLD6 & 96 \\
\hline 7 & G-C10-C11-G & CLD7 & 121 \\
\hline 8 & G-C12-C13-G & CLD8 & 250 \\
\hline \multicolumn{5}{c}{} & 1931 \\
\hline
\end{tabular}

Sumber: PT. XYZ

\subsection{Data Alat Angkut}

Pengiriman yang dilakukan menggunakan alat transportasi truk (Colt Diesel), data armada yang digunakan pendistribusiaan dari gudang ke customer sebagai berikut :

Tabel V. Kapasitas Armada

\begin{tabular}{cccc}
\hline Jenis Alat Angkut & Kapasitas & Jumlah & Keterangan \\
\hline CLD(Truck) & 600 Box & 8 & Milik Sendiri \\
\hline Sumber: PT. XYZ
\end{tabular}

\subsection{Data Biaya}

Biaya yang berkaitan dengan pengiriman produk dari gudang ke customer sebagai berikut:

Tabel VI. Kapasitas Biaya

\begin{tabular}{ccrrr}
\hline \multirow{2}{*}{ No } & \multirow{2}{*}{ Jenis Biaya } & \multicolumn{2}{c}{ Jumlah } & \multirow{2}{*}{ Ket } \\
\hline 1 & Bahan Bakar (solar) & $\mathrm{Rp}$ & 9.400 & / Liter \\
\hline \multirow{2}{*}{2} & \multirow{2}{*}{ Biaya Retribusi } & $\mathrm{Rp}$ & 50.000 & Jabodetabek \\
\cline { 3 - 5 } & & $\mathrm{Rp}$ & 200.000 & Subang \\
\cline { 3 - 5 } 3 & Biaya Konsumsi & $\mathrm{Rp}$ & $\mathrm{Rp} .000$ & Solo \\
\hline Sumber: PT. XYZ & & & \\
\end{tabular}

Keterangan : 1 liter mampu menempuh jarak $6 \mathrm{~km}$ jenis Truck (Colt Diesel).

a. Biaya bahan bakar

Rute $\mathrm{x}=$ Jarak customer $\mathrm{x} \frac{1}{\text { Jarak tempuh dalam } 1 \text { liter }} \times$ Harga BBM / litter

Rute $A=105 \times \frac{1}{6} \times$ Rp. $9.400=$ Rp. 164.500

Rute $\mathrm{B}=52 \times \frac{1}{6} \times$ Rp. $9.400=$ Rp. 81.466

Rute $\mathrm{C}=105 \times \frac{1}{6} \times$ Rp. $9.400=$ Rp. 164.500

Rute D $=132 \times \frac{1}{6} \times$ Rp. $9.400=$ Rp. 206.800

Rute $\mathrm{E}=1070 \times \frac{1}{6} \times \mathrm{Rp} .9 .400=\mathrm{Rp} .1 .676 .333$

Rute $\mathrm{F}=96 \times \frac{1}{6} \times \mathrm{Rp} .9 .400=$ Rp. 150.400

Rute $\mathrm{G}=121 \times \frac{1}{6} \times$ Rp. $9.400=$ Rp. 189.566

Rute $\mathrm{H}=250 \times \frac{1}{6} \times$ Rp. $9.400=$ Rp. 391.666 
Total jumlah biaya bahan bakar yaitu Rp. 3.025.231

b. Biaya konsumsi pengendara atau sopir/hari yaitu

Rp. 30.000 x $17=$ Rp. 510.000

c. Biaya Retribusi

Jabodetabek, x Rp. $50.000=$ Rp. 500.000

Subang x Rp. $200.000=$ Rp. 200.000

Solo, $x$ Rp. $500.000=$ Rp. 500.000

Total

$=$ Rp. 1.200 .000

Total biaya transportasi awal :

Total biaya bahan bakar + Total biaya konsumsi + Total biaya retribusi

$=$ Rp. 3.025.231+Rp. $510.000+$ Rp. 1.200 .000

= Rp. 4.735.231 / minggu atau Rp. 18.940.924 / bulan.

1. Jarak lokasi gudang ke customer

Tabel VII. Rata-rata pengiriman produk

\begin{tabular}{|c|c|c|c|c|c|c|c|c|c|c|c|c|c|c|c|}
\hline & GDG & C1 & $\mathrm{C} 2$ & C3 & $\mathrm{C} 4$ & C5 & C6 & C7 & C8 & C9 & $\mathrm{C} 10$ & C11 & $\mathrm{C} 12$ & $\mathrm{C} 13$ & $\mathrm{C} 14$ \\
\hline GDG & 0 & & & & & & & & & & & & & & \\
\hline $\mathrm{C} 1$ & 26 & 0 & & & & & & & & & & & & & \\
\hline $\mathrm{C} 2$ & 66 & 51 & 0 & & & & & & & & & & & & \\
\hline C3 & 31 & 51 & 95 & 0 & & & & & & & & & & & \\
\hline $\mathrm{C} 4$ & 23 & 36 & 51 & 51 & 0 & & & & & & & & & & \\
\hline C5 & 44 & 43 & 89 & 64 & 62 & 0 & & & & & & & & & \\
\hline C6 & 36 & 28 & 75 & 56 & 54 & 25 & 0 & & & & & & & & \\
\hline $\mathrm{C} 7$ & 23 & 57 & 101 & 22 & 55 & 71 & 63 & 0 & & & & & & & \\
\hline C8 & 30 & 43 & 87 & 15 & 41 & 40 & 50 & 44 & 0 & & & & & & \\
\hline C9 & 11 & 24 & 68 & 37 & 32 & 34 & 30 & 41 & 18 & 0 & & & & & \\
\hline $\mathrm{C} 10$ & 36 & 22 & 70 & 50 & 49 & 21 & 16 & 55 & 40 & 22 & 0 & & & & \\
\hline C11 & 52 & 49 & 95 & 72 & 71 & 15 & 33 & 77 & 45 & 41 & 33 & 0 & & & \\
\hline $\mathrm{C} 12$ & 122 & 107 & 67 & 155 & 108 & 139 & 134 & 161 & 146 & 128 & 127 & 155 & 0 & & \\
\hline $\mathrm{C} 13$ & 74 & 59 & 16 & 107 & 60 & 91 & 86 & 113 & 98 & 80 & 78 & 107 & 54 & 0 & \\
\hline $\mathrm{C} 14$ & 535 & 523 & 483 & 568 & 521 & 553 & 546 & 574 & 558 & 541 & 539 & 569 & 426 & 466 & 0 \\
\hline
\end{tabular}

Sumber: Google Maps

\subsection{Pengolahan Data}

\subsubsection{Penghematan Saving Matrix}

Pada perhitungan penghemat jarak dari lokasi gudang menuju customer menggunakan rumus :

$$
\mathrm{S}(\mathrm{C} 1, \mathrm{C} 2)=\mathrm{J}(\mathrm{G}, \mathrm{C} 1)+\mathrm{J}(\mathrm{G}, \mathrm{C} 2)-\mathrm{J}(\mathrm{C} 1, \mathrm{C} 2)
$$

Ket :

$\mathrm{S}(\mathrm{C} 1, \mathrm{C} 2)=$ Penghemat jarak customer 1 dengan customer 2

$\mathrm{J}(\mathrm{G}, \mathrm{C} 1) \quad=$ Jarak gudang ke customer 1

$\mathrm{J}(\mathrm{C} 1, \mathrm{C} 2)=$ Jarak customer 1 ke customer 2

Berikut perhitungan komsumen jenis box penghematan dalam sesuai km

Misal CI - C2

$$
\begin{aligned}
& \mathrm{S}(\mathrm{C} 1, \mathrm{C} 2)=\mathrm{J}(\mathrm{G}, \mathrm{C} 1)+\mathrm{J}(\mathrm{G}, \mathrm{C} 2)-\mathrm{J}(\mathrm{C} 1, \mathrm{C} 2) \\
& =26+66-51=41
\end{aligned}
$$


Tabel VIII. Matriks penghematan dalam sesuai $\mathrm{km}$

\begin{tabular}{|c|c|c|c|c|c|c|c|c|c|c|c|c|c|c|c|}
\hline & Rute & $\mathrm{C} 1$ & $\mathrm{C} 2$ & C3 & $\mathrm{C} 4$ & C5 & C6 & $\mathrm{C} 7$ & C8 & C9 & $\mathrm{C} 10$ & C11 & $\mathrm{C} 12 \mathrm{C}$ & $\mathrm{C} 13 \mathrm{C}$ & $\mathrm{C} 14$ \\
\hline $\mathrm{C} 1$ & 1 & 0 & & & & & & & & & & & & & \\
\hline $\mathrm{C} 2$ & 2 & 41 & 0 & & & & & & & & & & & & \\
\hline $\mathrm{C} 3$ & 3 & 6 & 2 & 0 & & & & & & & & & & & \\
\hline $\mathrm{C} 4$ & 4 & 13 & 38 & 3 & 0 & & & & & & & & & & \\
\hline C5 & 5 & 27 & 21 & 11 & 5 & 0 & & & & & & & & & \\
\hline $\begin{array}{ll}\text { C6 } \\
\end{array}$ & 6 & 34 & 27 & 11 & 5 & 55 & 0 & & & & & & & & \\
\hline $\begin{array}{l}\mathrm{C} 7 \\
\end{array}$ & 7 & -8 & -12 & 32 & -9 & -4 & -4 & 0 & & & & & & & \\
\hline $\mathrm{C} 8$ & 8 & 13 & 9 & 46 & 12 & 34 & 16 & 9 & 0 & & & & & & \\
\hline C9 & 9 & 13 & 9 & 5 & 2 & 21 & 17 & -7 & 23 & 0 & & & & & \\
\hline $\mathrm{C} 10$ & 10 & 40 & 32 & 17 & 10 & 59 & 56 & 4 & 26 & 25 & 0 & & & & \\
\hline C11 & 11 & 29 & 23 & 11 & 4 & 81 & 55 & -2 & 37 & 22 & 55 & 0 & & & \\
\hline $\mathrm{C} 12$ & 12 & 41 & 121 & -2 & 37 & 27 & 24 & -16 & 6 & 5 & 31 & 19 & 0 & & \\
\hline $\mathrm{C} 13$ & 13 & 41 & 124 & -2 & 37 & 27 & 24 & -16 & 6 & 5 & 32 & 19 & 28 & 0 & \\
\hline C14 & 14 & 38 & 118 & -2 & 37 & 26 & 25 & -16 & 7 & 5 & 2 & 18 & 27 & 143 & 0 \\
\hline
\end{tabular}

Selanjutnya langkah berikutnya pengurutan peringkat penghematan matrik dari jarak penghematan yang nilai terbesar terlebih dahulu sampai penghematan yang nilai terkecil sesuai dengan km-nya.

Tabel IX. Peringkat penghematan dalam sesuai km

\begin{tabular}{|c|c|c|c|c|c|c|c|}
\hline Peringkat & Nilai & Peringkat & Nilai & Peringkat & Nilai & Peringkat & Nilai \\
\hline 1 & 143 & 24 & 32 & 47 & 19 & 70 & 5 \\
\hline 2 & 124 & 25 & 32 & 48 & 18 & 71 & 5 \\
\hline 3 & 121 & 26 & 32 & 49 & 17 & 72 & 5 \\
\hline 4 & 118 & 27 & 31 & 50 & 17 & 73 & 4 \\
\hline 5 & 81 & 28 & 29 & 51 & 16 & 74 & 4 \\
\hline 6 & 59 & 29 & 28 & 52 & 13 & 75 & 3 \\
\hline 7 & 56 & 30 & 27 & 53 & 13 & 76 & 2 \\
\hline 8 & 55 & 31 & 27 & 54 & 13 & 77 & 2 \\
\hline 9 & 55 & 32 & 27 & 55 & 12 & 78 & 2 \\
\hline 10 & 55 & 33 & 27 & 56 & 11 & 79 & -2 \\
\hline 11 & 46 & 34 & 27 & 57 & 11 & 80 & -2 \\
\hline 12 & 41 & 35 & 26 & 58 & 11 & 81 & -2 \\
\hline 13 & 41 & 36 & 26 & 59 & 10 & 82 & -2 \\
\hline 14 & 41 & 37 & 25 & 60 & 9 & 83 & -4 \\
\hline 15 & 40 & 38 & 25 & 61 & 9 & 84 & -4 \\
\hline 16 & 38 & 39 & 24 & 62 & 9 & 85 & $\begin{array}{l}-7 \\
\end{array}$ \\
\hline 17 & 38 & 40 & 24 & 63 & 7 & 86 & -8 \\
\hline 18 & 37 & 41 & 23 & 64 & 6 & 87 & -9 \\
\hline 19 & 37 & 42 & 23 & 65 & 6 & 88 & -12 \\
\hline 20 & 37 & 43 & 22 & 66 & 6 & 89 & -16 \\
\hline 21 & 37 & 44 & 21 & 67 & 5 & 90 & -16 \\
\hline 22 & 34 & 45 & 21 & 68 & 5 & 91 & -16 \\
\hline 23 & 34 & 46 & 19 & 69 & 5 & & \\
\hline
\end{tabular}

Sumber: Pengolah Data

\subsubsection{Penentuan Alokasi Produk ke Customer Untuk Tiap Alat Angkut}

Setelah diurutkan peringkat yang tertinggi sampai yang terendah selanjutnya di iterasi, untuk menetukan rute, dan kapasitas yang pas pada setiap customer.

Tabel X. Hasil iterasi 10 dalam sesuai $\mathrm{km}$

\begin{tabular}{|c|c|c|c|c|c|c|c|c|c|c|c|c|c|c|}
\hline & Rute & $\mathrm{C} 1$ & $\mathrm{C} 2$ & C3 & $\mathrm{C} 4$ & $\mathrm{C} 5$ & C6 & C7 & $\mathrm{C} 8$ & C9 & $\mathrm{C} 10$ & $\mathrm{C} 11$ & C12 C13 & $\mathrm{C} 14$ \\
\hline $\mathrm{C} 1$ & $\mathrm{~B}$ & 0 & & & & & & & & & & & & \\
\hline $\mathrm{C} 2$ & $\mathrm{~B}$ & 41 & 0 & & & & & & & & & & & \\
\hline C3 & $\mathrm{D}$ & 6 & 2 & 0 & & & & & & & & & & \\
\hline $\mathrm{C} 4$ & $E$ & 13 & 38 & 3 & 0 & & & & & & & & & \\
\hline $\mathrm{C} 5$ & $\mathrm{C}$ & 27 & 21 & 11 & 5 & 0 & & & & & & & & \\
\hline C6 & $\mathrm{E}$ & 34 & 27 & 11 & 5 & 55 & 0 & & & & & & & \\
\hline $\mathrm{C} 7$ & $\mathrm{D}$ & -8 & -12 & 32 & -9 & -4 & -4 & 0 & & & & & & \\
\hline $\mathrm{C} 8$ & $\mathrm{D}$ & 13 & 9 & 46 & 12 & 34 & 16 & 9 & 0 & & & & & \\
\hline C9 & $\mathrm{D}$ & 13 & 9 & 5 & 2 & 21 & 17 & -7 & 23 & 0 & & & & \\
\hline $\mathrm{C} 10$ & $\mathrm{C}$ & 40 & 32 & 17 & 10 & 59 & 56 & 4 & 26 & 25 & 0 & & & \\
\hline C11 & $\mathrm{C}$ & 29 & 23 & 11 & 4 & 81 & 55 & -2 & 37 & 22 & 55 & 0 & & \\
\hline C12 & $\mathrm{B}$ & 41 & 121 & -2 & 37 & 27 & 24 & -16 & 6 & 5 & 31 & 19 & 0 & \\
\hline C13 & $\mathrm{A}$ & 41 & 124 & -2 & 37 & 27 & 24 & -16 & 6 & 5 & 32 & 19 & 280 & \\
\hline $\mathrm{C} 14$ & $\mathrm{~A}$ & 38 & 118 & -2 & 37 & 26 & 25 & -16 & 7 & 5 & 2 & 18 & $27 \quad 143$ & 0 \\
\hline
\end{tabular}

Sumber: Pengolah Data 


\subsubsection{Pengurutan dan Rute Baru}

Berdasarkan alokasi kendaraan penentuan alokasi produk ke customer untuk tiap alat angkut diperoleh jarak saving matrix sebagai berikut :

a. Rute baru pengiriman saving matrix

Rute A

Pada penentuan rute A menggunakan saving matrix diperoleh solusi (G-C13-C14G) dengan jumlah jaraknya.

Rute $\mathrm{A}=74 \mathrm{~km}+466 \mathrm{~km}+535 \mathrm{~km}$

$$
=1075 \mathrm{~km}
$$

Rute B

Pada penentuan rute B menggunakan saving matrix diperoleh solusi (G-C2-C12-C1G) dengan jumlah jaraknya.

Rute $\mathrm{B}=66 \mathrm{~km}+67 \mathrm{~km}+107 \mathrm{~km}+26 \mathrm{~km}$

$$
=266 \mathrm{~km}
$$

Rute C

Pada penentuan rute $\mathrm{C}$ menggunakan saving matrix diperoleh solusi (G-C5-C11C10-G) dengan jumlah jaraknya.

Rute $\mathrm{C}=44 \mathrm{~km}+15 \mathrm{~km}+33 \mathrm{~km}+36 \mathrm{~km}$

$$
=128 \mathrm{~km}
$$

\section{Rute D}

Pada penentuan rute D menggunakan saving matrix diperoleh solusi (G-C3-C8-C7C9-G) dengan jumlah jaraknya.

Rute $\mathrm{D}=31 \mathrm{~km}+15 \mathrm{~km}+44 \mathrm{~km}+41 \mathrm{~km}+11 \mathrm{~km}$

$$
=142 \mathrm{~km}
$$

Rute E

Pada penentuan rute E menggunakan saving matrix diperoleh solusi (G-C4-C6-G) dengan jumlah jaraknya.

Rute $\mathrm{E}=23 \mathrm{~km}+54 \mathrm{~km}+36 \mathrm{~km}$

$$
=113 \mathrm{~km}
$$

b. Pengurutan rute pengiriman dengan prosedur neurest neighbor.

Hasil iterasi pengalokasian kendaraan berdasarkan metode saving matrix diperoleh 5 rute konsumen jenis box yaitu rute $\mathrm{A}$ : $(\mathrm{C} 13, \mathrm{C} 14)$, rute $\mathrm{B}:(\mathrm{C} 2, \mathrm{C} 12, \mathrm{C} 1)$, rute $\mathrm{C}:(\mathrm{C} 5, \mathrm{C} 11, \mathrm{C} 10)$, rute $\mathrm{D}:(\mathrm{C} 3, \mathrm{C} 8, \mathrm{C} 7, \mathrm{C} 9)$, dan rute $\mathrm{E}:(\mathrm{C} 4, \mathrm{C} 6)$.

Metode neurest neighbor merupakan metode yang digunakan untuk menentukan jarak rute terpendek dengan jarak yang paling terdekat antara customer satru dengan customer yang lainnya, antara lain sebagai berikut:

Rute A (G-C13-C14-G)

\section{Iterasi 1}

Awal perjalanan dimulai dari gudang $(\mathrm{G})$ dengan total $=0 \mathrm{~km}$

Tabel XI Iterasi 1 rute A dalam satuan km

\begin{tabular}{cc}
\hline Kode & Jarak dari gudang $(\mathrm{G})$ \\
\hline $\mathrm{C} 13$ & 74 \\
\hline $\mathrm{C} 14$ & 535 \\
\hline
\end{tabular}

Sumber: Pengolah Data 
Ukuran jarak tersebut dapat dilihat pada tabel VII . Pengiriman dilihat dari lokasi terdekat terlebih dahulu maka diperoleh rute gudang (G) menuju customer 13 (C13)

Iterasi 2

Perjalanan dimulai dari $\mathrm{C} 13$ dengan total jarak $=0 \mathrm{~km}$

Tabel XIII Iterasi 2 rute A dalam satuan $\mathrm{km}$

\begin{tabular}{cc}
\hline Kode & Jarak dari Customer 13 \\
\hline $\mathrm{C} 13$ & 0 \\
\hline $\mathrm{C} 14$ & 466 \\
\hline
\end{tabular}

Sumber: Pengolah Data

Ukuran jarak tersebut dapat dilihat pada tabel VII . Pengiriman dilihat dari lokasi terdekat terlebih dahulu maka diperoleh rute customer 13 (C13) menuju customer 14 (C14). Setelah menggunakan perhitungan nearest neighbor diperoleh solusi dari (GC13-C14-G) dengan jumlah jarak :

$$
\text { Rute } \mathrm{A}=74 \mathrm{~km}+466 \mathrm{~km}+535 \mathrm{~km}=1075 \mathrm{~km}
$$

Dan seterusnya sampai rute E menggunakan perhitungan nearest neighbor.

\subsubsection{Rute baru pengiriman}

Berdassarkan hasil pengurutan rute ,aka diperoleh jumlah jarak pengiriman untuk pendistribusian kepada customer jumlah order size sebagai berikut:

Rute A

(G-C3-C14-G) dengan jumlah jarak :

Rute $\mathrm{A}=74 \mathrm{~km}+466 \mathrm{~km}+535 \mathrm{~km}=1075 \mathrm{~km}$

Jumlah order $=340$ box +200 box $=540$ box

Rute B

(G-C1-C2-C12-G) dengan jumlah jarak :

Rute $\mathrm{B}=26 \mathrm{~km}+51 \mathrm{~km}+67 \mathrm{~km}+122 \mathrm{~km}=266 \mathrm{~km}$

Jumlah order $=300$ box +150 box +100 box $=550$ box

Rute C

(G-C10-C5-C11-G) dengan jumlah jarak :

Rute $\mathrm{C}=36 \mathrm{~km}+21 \mathrm{~km}+15 \mathrm{~km}+52 \mathrm{~km}=124 \mathrm{~km}$

Jumlah order $=200$ box +200 box +150 box $=550$ box

Rute D

(G-C9-C8-C3-C7-G) dengan jumlah jarak :

Rute $\mathrm{D}=11 \mathrm{~km}+18 \mathrm{~km}+15 \mathrm{~km}+22 \mathrm{~km}=66 \mathrm{~km}$

Jumlah order $=200$ box +180 box +120 box +100 box $=600$ box

Rute E

(G-C4-C6-G) dengan jumlah jarak :

Rute $\mathrm{E}=23 \mathrm{~km}+54 \mathrm{~km}+36 \mathrm{~km}=113 \mathrm{~km}$

Jumlah order $=200$ box +210 box $=410$ box 
4.6.5. Pehitungan biaya transportasi

Setelah penerapan metode nearest neighbor maka didapatkan biaya dan rute baru sebagai berikut :

Rute $\mathrm{x}=$ Jarak customer $\mathrm{x} \frac{1}{\text { Jarak tempuh dalam } 1 \text { liter }} \times$ Harga BBM/litter

Rute $A=1075 \times \frac{1}{6} \times$ Rp. $9.400=$ Rp. 1.684 .166

Rute $\mathrm{B}=266 \times \frac{1}{6} \times \quad$ Rp. $9.400=$ Rp. 416.733

Rute $\mathrm{C}=124 \times \frac{1}{6} \times$ Rp. $9.400=$ Rp. 194.266

Rute $\mathrm{D}=66 \times \frac{1}{6} \times$ Rp. $9.400=$ Rp. 103.400

Rute $\mathrm{E}=113 \times \frac{1}{6} \times \quad$ Rp. $9.400=$ Rp. 177.033

Total jarak, rute setelah penerapan metode nearest neighbor yaitu 1644 km. Sehingga diperoleh keseluruhan biaya transportasi berdasarkan rute usulan tersebut sebesar :

Rute A : (G-C13-C14-G) = Rp. 1.684.166

Rute B : (G-C1-C2-C12-G) = Rp. 416.733

Rute C : (G-C10-C5-C11-G) = Rp. 194.266

Rute D : (G-C9-C8-C3-C7-G) = Rp. 103.400

Rute E : (G-C4-C6-G) = Rp. 177.033

Total $=$ Rp. 2.575 .598

Biaya konsumsi pengendara atau sopir/hari yaitu

Rp. $30.000 \times 10=$ Rp. 300.000

Biaya Retribusi

Jabodetabek, x Rp. $50.000=$ Rp. 500.000

Subang x Rp. $200.000=$ Rp. 200.000

Solo, $x$ Rp. $500.000=$ Rp. 500.000

Total = Rp. 1.200 .000

Total biaya transportasi awal :

Total biaya bahan bakar + Total biaya konsumsi + Total biaya retribusi

$=$ Rp. $2.575 .598+$ Rp. $300.000+$ Rp. 1.200 .000

= Rp. 4.075.598 / minggu atau Rp. 16.302.392 / bulan.

Sehingga didapatkan penghematan sebesar :

= Biaya awal - Biaya usulan

$=$ Rp. 4.735.231-Rp. 4.075.598 = Rp. 659.633.

4.6. Analisis Rute Distribusi

Hasil dari pengolahan data menggunakan metode saving matrix yaitu memperoleh rute baru sebanyak 5 rute. PT. XYZ pendistribusian menggunakan alat angkut truck yang berjenis CLD (Colt Diesel). Pengiriman setiap rute masing-masing mendapatkan satu armada mendapat 2 orang dalam 1 truck, dan rutenya tersebut dibagi ke rute $\mathrm{A}$, rute $\mathrm{B}$, rute $\mathrm{C}$, rute $\mathrm{D}$ dan rute $\mathrm{E}$. Pengalokasian customer beban pada setiap 
masing-masing armada yaitu rute A membawa beban sebanyak 540 box, rute B sebanyak 550 box, rute $C$ sebanyak 550 box, rute D sebanyak 600 box dan rute D sebanyak 410 box.

\subsubsection{Rute Baru Pengiriman}

a. Rute baru menggunakan metode saving matrix

Setelah diperoleh rute pengiriman menggunakan metode saving matrix yang digunakan untuk memperoleh rute terpendek berdasarkan kapasitas yang dimiliki perusahaan. Rute baru menggunakan metode saving matrix sebagai berikut:

Rute A : (G-C13-C14-G)

Rute B : (G-C2-C12-C1-G)

Rute C : (G-C5-C11-C10-G)

Rute D : (G-C3-C8-C7-C9-G)

Rute E : (G-C4-C6-G)

Berikut ini adalah perubahan jarak awal pengiriman dan jarak setelah menggunakan metode saving matrix.

\begin{tabular}{cccc}
\multicolumn{4}{c}{ Tabel XIV. Jarak saving matrix } \\
\hline $\begin{array}{c}\text { Total jarak awal } \\
(\mathrm{km})\end{array}$ & $\begin{array}{c}\text { Total jarak saving } \\
\text { matrix }(\mathrm{km})\end{array}$ & Selisih jarak $(\mathrm{km})$ & $\begin{array}{c}\text { Hemat } \\
(\%)\end{array}$ \\
\hline 1931 & 1724 & 207 & $11 \%$ \\
\hline
\end{tabular}

Sumber: Pengolah Data

b. Rute baru menggunakan metode nearest neighbor

Pengurutan rute menggunakan metode nearest neighbor, menurut suparjo (2009) menggunakan metode nearest neighbor dapat menghasilkan rute kendaraan pada customer terpilih berdasarkan customer terdekat. Rute baru menggunakan metode nearest neighbor yaitu

Rute A : (G-C13-C14-G)

Rute B : (G-C1-C2-C12-G)

Rute C : (G-C10-C5-C11-G)

Rute D : (G-C9-C8-C3-C7-G)

Rute E : (G-C4-C6-G)

Berikut ini adalah perubahan jarak awal pengiriman dan jarak setelah menggunakan metode nearest neighbor.

\begin{tabular}{cccc}
\multicolumn{4}{c}{ Tabel XV. Jarak nearest neighbor } \\
\hline $\begin{array}{c}\text { Total jarak saving } \\
\text { matrix }(\mathrm{km})\end{array}$ & $\begin{array}{c}\text { Total jarak nearest } \\
\text { neighbor }(\mathrm{km})\end{array}$ & Selisin jarak $(\mathrm{km})$ & $\begin{array}{c}\text { Hemat } \\
(\%)\end{array}$ \\
\hline 1724 & 1644 & 80 & $5 \%$ \\
\hline
\end{tabular}

4.6.2. Analisi Biaya Pengiriman

Sumber: Pengolah Data

Biaya merupakan alat pembayaran, hal yang harus diperhatikan untuk mendukung berjalannya pengiriman pada perusahaan. Berikut ini adalah biaya usulan setelah menggunakan metode nearest neighbor. 
Tabel XVI. Biaya usualan nearest neighbor

\begin{tabular}{cccc}
\hline Total biaya awal (Rp) & $\begin{array}{c}\text { Total biaya nearest } \\
\text { neighbor (Rp) }\end{array}$ & Selisih biaya (Rp) & $\begin{array}{c}\text { Hemat } \\
(\%)\end{array}$ \\
\hline Rp. 4.735.231 & Rp. 4.075.598 & Rp. 659.633 & \\
Atau & Atau & Atau & $14 \%$ \\
Rp. 18.940.924 / bln & Rp. 16.302.392 / bln & Rp. 2.638.532 & \\
\hline
\end{tabular}

Sumber: Pengolah Data

\section{Kesimpulan dan Saran}

Berdasarkan hasil penelitian yang telah dilakukan, maka diperoleh suatu kesimpulan yaitu: Pada pendistribusian awal perusahan menggunakan 8 rute setelah menggunakan metode saving matrix berubah menjadi 5 rute baru, dimana urutan rute usulan menggunakan metode nearest neighbor dimulai dari rute A sampai rute E dengan jarak tempuh awal 1931 $\mathrm{km}$ setelah menggunakan metode nearest neighbor menjadi $1644 \mathrm{~km}$ atau penghematan sebesar 16\%, pendistribusian menggunakan 5 truck yang berjenis CLD (Cold diesel) yang berkapasitas 600 box. Rute yang diperoreh setelah menggunakan metode nearest neighbor sebaagai berikut :

- Rute A : (G-C13-C14-G) dengan jarak 1075 km

- Rute B : (G-C1-C2-C12-G) dengan jarak 266 km

- Rute C : (G-C10-C5-C11-G) dengan jarak 124 km

- Rute D : (G-C9-C8-C3-C7-G) dengan jarak 66 km

- Rute E : (G-C4-C6-G) dengan jarak 113 km

Setelah mendapatkan urutan rute baru menggunakan metode nearest neighbor, biaya pengiriman pada rute awal sebesar Rp. 18.940.924 / bulan tetapi setelah menggunakan metode saving matrix diperoleh biaya pengiriman sebesar Rp. 16.302.392 / bulan . Minimasi biaya diusulkan berdasarkan pengiriman kepaada customer menggunakan metode nearest neighbor dengan menghemat biaya pengiriman sebesar 16\%, yang beralokasi Jabodetabek, Cikampek Subang, Solo lebih minimum dengan pengiriman yang tidak melebihi kapasitas armada melalui pengurutan rute yang paling dekat. Pengiriman selanjutnya diharapkan perusahaan dapat menggunakan jalur pendistribusian baru dengan menggunakan metode saving matrix dan metode nearest neighbor, agar biaya pengirimannya dapat dikendalikan dengan melalui jalur pengiriman yang lebih pendek atau terdekat dan biayanya menjadi optimum.

\section{Daftar Pustaka}

[1] Muhammad, Bakhtiar, and M. Rahmi, "Penentuan Rute Transportasi Distribusi Sirup Untuk Meminimalkan Biaya," Ind. Eng. J., vol. 6, no. 1, pp. 10-15, 2017.

[2] N. Aprilia, "Penerapan Metode Saving Matrix Untuk Meminimasi Biaya Pengiriman Produk Kemasan Pada PT XYZ,” Tek. Ind., vol. 1, no. 1, pp. 5-9, 2019.

[3] N. Ikfan and M. Ilyas, "Penentuan rute Transportasi Terpendek untuk Meminimalkan Biaya Menggunakan Metode Saving Matriks," J. Ilm. Tek. Ind., vol. 12, no. 2, pp. 165-178, 2013. 
[4] A. Momon and D. W. Ardiatma, "Penentuan Rute Distribusi Suku Cadang Kendaraan Bermotor dalam Meminimalkan Biaya Transportasi (Studi Kasus: PT. Inti Polymetal Karawang)," JIEMS (Journal Ind. Eng. Manag. Syst., vol. 11, no. 1, pp. 17-24, 2018.

[5] T. J. Pattiasina, E. T. Setyoadi, and D. Wijayanto, "Saving matrix method for efficient distribution route based on google maps API," J. Telecommun. Electron. Comput. Eng., vol. 10, no. 2-3, pp. 183-188, 2018.

[6] F. J. Sesa, H. Syarifudin, and Y. Rizal, "Optimasi Rute Pengiriman Produk dengan Meminimumkan Biaya Transportasi Menggunakan Metode Saving Matrix di PT . DEF," vol. 2, no. 4, pp. 18-22, 2016.

[7] R. Yuniarti and M. Astuti, "Penerapan Metode Saving Matrix Dalam Penjadwalan Dan Penentuan Rute Distribusi Premium Di SPBU Kota Malang," Rekayasa Mesin, vol. 4, no. 1, pp. 17-26, 2013.

[8] Suparjo, "METODE SAVING MATRIX SEBAGAI METODE ALTERNATIF UNTUK EFISIENSI BIAYA DISTRIBUSI (Studi Empirik Pada Perusahaan Angkutan Kayu Gelondongan Di Jawa Tengah)," Media Ekon. Dan Manaj., vol. 32, no. 2, pp. 137-153, 2017.

[9] Suparjo, "Use Of The Saving Matrix Method As An Alternative For Distribution Cost Efficiency: An Empirical Study On Log Timber Companies In Central Java," Int. J. Sci. Technol. Res., vol. 8, pp. 398-402, 2019.

[10] A. Sutoni and I. Apipudin, "Optimalisasi Penentuan Rute Distribusi Pupuk Untuk Meminimalkan Biaya Transportasi Dengan Metode Saving Matrix," Spektrum Ind., vol. 17, no. 2, p. 143, 2019.

[11] S. Supriyadi, K. Mawardi, and A. Nalhadi, "Minimasi Biaya Dalam Penentuan Rute Distribusi Produk Minuman Menggunakan Metode Savings Matrix," Semin. Nas. Inst. Supply Chain dan Logistik Indones. Univ. Hasanuddin Makasar, no. September, pp. 1-8, 2017.

[12] M. Maulidiah, J. Jono, and I. R. Ramli, "Penentuan Rute Penyaluran Bantuan Bencana Guna Meminimalkan Biaya Distribusi Dengan Metode Saving Matriks," J. Rekayasa Ind., vol. 1, no. 1, 2019.

[13] R. Putrafi, "PENYELESAIAN VEHICLE ROUTING PROBLEM UNTUK EFISIENSI RUTE M ENG G UN AKA N M ETO D E SAVI NG M ATRI K S," vol. $17,2020$.

[14] N. F. Ade Irman SM, Ratna Ekawati, "Optimalisasi Rute Distribusi Air Minum Quelle Dengan Algoritma Clarke \& Wright Saving Dan Model Vehicle Routing Problem," pp. 1-7, 2017.

[15] D. Agustina and M. Fauzi, "Penentuan Rute Distribusi Terpendek Menggunakan Metode Saving Matrix Dan Cluster First-Route Second ( Studi Kasus PT . Herbalife cabang Yogyakarta ),” pp. 60-68, 2016.

[16] S. Basriati and R. Sunarya, "Optimasi Distribusi Koran Menggunakan Metode Saving Matriks ( Studi Kasus : PT . Riau Pos Intermedia ),” no. November, pp. 448-453, 2015.

[17] J. O. Ong and Saraka Arianto, "Implementasi Distribusi Requirement Planning dan 
Saving Matrix untuk Meminimasi Total Biaya Distribusi di Industri Bahan Kimia," J. Ilm. Tek. Ind., vol. 12, no. 2, pp. 152-164, 2013.

[18] S. R. F. Fitri, "Optimasi Jalur Distribusi Produk Dengan Menggunakan Metode Saving Matrix untuk Penghematan Biaya Operasional," J. Valtech, vol. 1, no. 1, pp. 103-109, 2018.

[19] H. P. MUHAMMAD ABELL AMANDA, ARIF IMRAN, "PENENTUAN RUTE DISTRIBUSI UNTUK MINIMASI BIAYA DISTRIBUSI TEH WALINI READY TO DRINK DI PT PERKEBUNAN NUSANTARA VIII (PERSERO)," J. Online Inst. Teknol. Nas., vol. 03, no. 01, pp. 260-271, 2015.

[20] M. A. K. Parikesit, Yuliati, P. R. Angka, A. Gunadhi, A. Joewono, and R. Sitepu, "PENENTUAN RUTE TERPENDEK DENGAN METODE TABU SEARCH (STUDI KASUS),” Sci. J. Widya Tek., vol. 17, no. 2, pp. 63-71, 2018.

[21] Lukmandono, M. Basuki, M. J. Hidayat, and F. B. Aji, “Application of Saving Matrix Methods and Cross Entropy for Capacitated Vehicle Routing Problem (CVRP) Resolving," IOP Conf. Ser. Mater. Sci. Eng., vol. 462, no. 1, 2019.

[22] N. S. Dini, "Optimasi Penentuan Rute Kendaraan Distribusi Produk Air Minum Kemasan Galon Menggunakan Kombinasi Algoritma Genetika Dan Pencarian Tabu Di Depot Air Minum Isi Ulang Banyu Belik, Purwokerto," vol. 19, no. 01, p. 136, 2015.

[23] F. Ahmad and H. F. Muharram, "Penentuan Jalur Distribusi Dengan Metode Saving Matriks," Competitive, vol. 13, no. 1, p. 45, 2018. 